\title{
CONFLICT OF LAWS REGULATION OF CONTRACTUAL DISPOSITIONS UPON DEATH: SHOULD UKRAINE FOLLOW THE EU'S APPROACH?
}

Prof. Dr. Iryna Dikovska*

UDK: 341.9: 347.232.8(477)

347.44:347.68(477)

339.923:061.1](477:4EU)

DOI: 10.3935/zpfz.69.3.03

Pregledni znanstveni rad

Primljeno: listopad 2018.

The paper analyses a possible conflict of laws regulation regarding an inheritance contract under current Ukrainian Private International Law in the absence of special conflict of laws rules that are applicable to contractual dispositions upon death. Since the EU Succession Regulation contains special conflict of laws rules applicable to the agreements as to succession, this paper evaluates the possibility of using its approaches for conflict of laws regulation of inheritance contracts, as they are known in Ukrainian law. Thus, this paper analyses the characterization of the agreement as to succession and conflict of laws rules applicable to it under the EU Succession Regulation. It is concluded that most of the rules of the EU Succession Regulation of the agreements as to succession should be accepted by Ukrainian legislation.

Key words: conflict of laws regulation of contractual dispositions upon death, inheritance contract, agreement as to succession, the EU Succession Regulation, Ukrainian Private International Law

\footnotetext{
Iryna Dikovska, Dr. Jur., Associate Professor, Faculty of Law, Taras Shevchenko National University of Kyiv, 60 Volodymyrska Street, Kyiv, Ukraine; irinadikovska@ hotmail.com;
}

ORCID ID: orcid.org/0000-0002-0728-3934 


\section{INTRODUCTION**}

The civil laws of some countries allow for conclusion of agreements, providing the possibility of dispensing of property upon death. Ukrainian law also has such an agreement: the inheritance contract. This notion is relatively new to the Ukrainian legal system since the legislation before 2004 (the year of coming into force of the Civil Code of Ukraine) ${ }^{1}$ did not provide for it. The inheritance contract has several advantages over similar legal notions. For instance, the transfer of ownership under the inheritance contract occurs only after the death of the transferor. ${ }^{2}$ Thus, a transferor under an inheritance contract is more protected than the transferor under a life care contract. ${ }^{3}$ Conversely, the rules concerning reserved portions in inheritance do not extend to the estate, which is transferred under the inheritance contract. ${ }^{4}$ Therefore, a transferee is in a better position than an heir under a will. ${ }^{5}$ Thus, despite Ukrainians being more accustomed to wills and life care contracts than to inheritance contracts ${ }^{6}$, one can predict the increasing use of the latter.

** The author is grateful to Max Planck Institute for Comparative and International Private Law for hospitality and financial support, which allowed her to compose this paper as a visiting researcher of the Institute.

1 Tsyvilnyi kodeks Ukrainy (the Civil Code of Ukraine), Vidomosti Verkhovnoi Rady Ukrainy (Bulletin of Verkhovna Rada of Ukraine) No. 40 item 356/2003, hereinafter: CCU.

2 CCU, Art. 1302.

3 According to Article 748 of CCU, under a life care contract, the transfer of ownership of an asset, which is subject to this contract, occurs at the moment of its notarization or, in cases of immovable property, at the moment of its state registration.

4 Postanova Plenumu Verkhovnoho Sudu Ukrainy 'Pro sudovu praktyku u spravakh pro spadkuvannia' (Resolution of the Plenary Session of the Supreme Court of Ukraine 'On court practice in succession matters'), Visnyk Verkhovnoho sudu Ukrainy (Bulletin of the Supreme Court of Ukraine) No. 6 item 17/2008, Art. 28, para. 1.

5 For detailed analyses of the advantages of an inheritance contract under Ukrainian law see: Krasytska, O., Perevahy ta ryzyky spadkovoho dohovoru (Advantages and Risks of an Inheritance Contract) in Kuznetsova, N., Martynenko, I.; Borysova, V.; Maidanyk, R. (eds.), Problemy Tsyvilnoho Prava Ta Protsesu: tezy dopovidei uchasnykiv naukovo-praktychnoi konferentsii, prysviachenii pamiati O. A. Pushkina (Problems of Civil Law and Procedure: Abstracts of Reports of the Participants of the Scientific-Practical Conference, in Tribute to the Memory of O. A. Pushkin), KhNUVS, Kharkiv, 2017, pp. 102-106.

6 Prokhor, L., Spadkovyi dohovir: praktyka zastosuvannia (Inheritance Contract: Practice of Use), Mala entsyklopediia notariusa (Small Encyclopedia of a Notary), vol. 64, no. 4, 2012, p. 62. 
At the same time, the migration rate, which has been growing in Ukraine in recent years ${ }^{7}$, increases the likelihood of the emergence of foreign element ${ }^{8}$ in such contracts, raising a number of issues, including the law applicable to inheritance contracts. The conflict of laws rules, which resolve questions of the law applicable to inheritance contracts, should be sought in the Law of Ukraine 'On Private International Law', which includes the main body of Ukrainian conflict of laws rules. However, it does not include any special rules applicable to inheritance contracts. Therefore, this paper analyses the possible ways to determine the law applicable to inheritance contracts in the absence of special rules. To determine the conflict of laws rules that might be applicable in this situation, we first consider PILA's rules for characterization and analyse the views on the legal nature of inheritance contracts in Ukrainian Civil Law.

Since the EU Succession Regulation ${ }^{10}$ contains special conflict of laws rules applicable to agreements as to succession, this paper attempts to evaluate the possibility of using its approaches to the conflict of laws regulation of inheritance contracts, as known in Ukrainian law. For this reason, we consider the characterization of agreements as to succession and conflict of laws rules applicable to it under SR.

7 Tyshchuk, T., The Great Migration: No One in Ukraine Knows How Many of Our Compatriots Have Moved Abroad, https://voxukraine.org/en/the-great-migration-no-one-inukraine-knows-how-many-of-our-compatriots-have-moved-abroad (4.10.2018).

8 According to Article 1 of the Law of Ukraine 'On Private International Law', the 'foreign element' appears in relationships in which: at least one of the parties to the legal relationship is a citizen of Ukraine, who lives abroad, a foreigner, a stateless person or a foreign legal entity; the object of the legal relationship is in the territory of a foreign state; or a legal fact that creates, changes or terminates legal private relationship exists in the territory of the foreign state.

9 Zakon Ukrainy 'Pro mizhnarodne pryvatne pravo' (the Law of Ukraine 'On Private International Law'), Holos Ukrainy (Vox of Ukraine), no 138/2005, hereinafter: PILA. PILA was adopted on the $23^{\text {rd }}$ of June 2005 and came into force on the $1^{\text {st }}$ of September 2005.

10 Regulation (EU) No 650/2012 of the European Parliament and of the Council of 4 July 2012 on jurisdiction, applicable law, recognition and enforcement of decisions and acceptance and enforcement of authentic instruments in matters of succession and on the creation of a European Certificate of Succession, OJ L 201, 27 July 2012, hereinafter: SR. 


\section{CHARACTERIZATION OF THE AGREEMENTS AS TO SUCCESSION IN UKRAINIAN PRIVATE INTERNATIONAL LAW}

Under the general rule, recognized in Ukrainian Law, the determination of the legal nature of the relationships with foreign element (the first characterization) must be performed under the law of Ukraine. ${ }^{11}$ The foreign law 'may be taken into account' if 'the rules and notions that are to be characterized are unknown to Ukrainian law or are known under another name or have another content and cannot be determined by interpretation under Ukrainian law'. ${ }^{12}$ As one of the drafters of PILA explained, the wording 'may be taken into account' was chosen instead of the wording 'may be applied' because 'the goal of Article 7 is not to apply a foreign law but to consider the possibility of such application.'. ${ }^{13}$

Since Ukrainian law incorporates the notion of the inheritance contract ('spadkovyi dogovir'), one can assume with great probability that, if a Ukrainian court settles a dispute arising out of such a contract with a foreign element, it will clarify the legal nature of the relationships arising out of this agreement under Ukrainian law.

Under the inheritance contract one party (the transferee) is obliged to fulfil all of the dispositions of the second party (the transferor) and, in case of the latter's death, acquires the ownership of the transferor's estate. ${ }^{14}$ Under this contract, both spouses, one of them or 'any other person' may act as a transferor. ${ }^{15}$ However, since the transfer of the estate is connected with the death of the transferor, it is the only natural person who may be a transferor under the

11 PILA, Art. 7, para. 1, which states that: 'To determine the applicable law, a court or other authority is guided by the interpretation of rules and notions according to the law of Ukraine'.

12 Ibid., Art. 7, para. 2.

13 Kysil, V., Diia i tlumachennia koliziinykh norm (Effect and Interpretation of Conflict of Laws Rules) in Dovhert, A. S.; Kysil, V. I. (eds.), Mizhnarodne Pryvatne Pravo: pidruchnyk (International Private Law: Handbook), Alerta, Kyiv, 2014, p. 181. However, it is unclear why the legislator used the wording 'a court ... is guided ... by the rules' when it mentioned the characterization under Ukrainian law and wording that a foreign law 'may be considered' when it comes to the characterization under foreign law. In our opinion, it would be more appropriate to use the wording 'a court or other authority is guided by the rules and notions of a foreign law if the rules and notions that are to be characterized are unknown to Ukrainian law or are known under another name or have another content'.

14 CCU, Art. 1302.

15 CCU, Art. 1303, para. 1. 
inheritance contract. ${ }^{16}$ The circle of potential transferees includes natural, as well as legal, persons. ${ }^{17}$ As follows from Article 1305 of CCU, a transferor may impose on the transferee the duties to fulfil the actions of a property or non-property character, which are to be fulfilled before or after the death of the transferor.

Despite the rules on the agreement as to succession being included in Book 6 of CCU, which is called 'Succession Law', most researchers believe that the relationships arising out of this agreement are not of succession but of a contractual nature. ${ }^{18}$ The main reason for this suggestion is that an agreement as to succession is not mentioned in Article 1217 of CCU among the grounds for succession. ${ }^{19}$ This point of view was supported by the Supreme Court of Ukraine, the conclusion of which went beyond this reason and stated that 'since the transfer of the assets from the transferor to the transferee under the agreement as to succession does not belong to any type of succession, the rules on succession ... do not regulate the relationships arising out of this agreement'. ${ }^{20}$ However, another position, under which an inheritance contract provided by Article 1302 of CCU constitutes the grounds for succession can also be found in Ukrainian legal doctrine. ${ }^{21}$ The author pointed out the double nature of inheritance contracts provided by Article 1302 of CCU: on the one hand, they are the disposition upon death; and on the other hand, they are contracts. ${ }^{22} \mathrm{An}$ important feature of this conclusion is that it was made as a result of research of the nature of the relationships arising out of inheritance contracts, rather than on the basis of mere consideration of the article of CCU, which sets the grounds for succession.

16 Kukhariev, O., Spadkove pravo Ukrainy (Succession Law of Ukraine), Alerta, Kyiv, 2013, p. 315.

17 CCU, Art. 1303, para. 2.

18 Riabokon, Y., Spadkovyi dohovir (Inheritance Contract) in Zaika, Y.; Riabokon, Y., Spadkove pravo: navchalnyi posibnyk (Succession Law: A Handbook), Yurinkom Inter, Kyiv, 2009, pp. 159-199; Kukhariev, O., Vykonannia spadkovoho dohovoru: notarialna ta sudova praktyka (The Performance of the Inheritance Contract: Notarial and Court Practice), Mala Entsyklopediia Notariusa (Small Encyclopedia of a Notary), vol. 89, no. 5, 2016, pp. 140-149.

19 Riabokon, Y., op. cit. (fn. 18), pp. 169-170; Kukhariev, O., op. cit. (fn. 18), p. 140.

20 Postanova Plenumu Verkhovnoho Sudu Ukrainy 'Pro sudovu praktyku u spravakh pro spadkuvannia', op. cit. (fn. 4), Art. 28, para. 1.

21 Shama, N., Pravova pryroda spadkovoho dohovoru (Legal Nature of the Inheritance Contract), Universytetski naukovi zapysky (University Scientific Notes), vol. 18, no. 2, 2006, p. 148. 
In our point of view, an inheritance contract is of a binary nature. On the one hand, it is a disposition upon death because, by its conclusion, the transferor determines the fate of the estate in the case of his or her death. On the other hand, the inheritance contract enters into force only if both parties have expressed their intention to be bound by it, and it gives rise to the transferor's rights and transferee's duties. Therefore, all characteristics of the contract, as 'an agreement between two or more parties, which is intended to give rise to, modify or terminate the civil rights and duties, ${ }^{23}$ are inherent in it. Thus, in general, it can be determined to be a contractual disposition upon death.

\section{LAW APPLICABLE TO AGREEMENTS AS TO SUCCESSION UNDER UKRAINIAN PRIVATE INTERNATIONAL LAW: CURRENT STATE}

PILA does not include any special rules applicable to inheritance contracts. In this situation, the rules of procedural codes, which allow for the application of the analogy of legislation or analogy of law (if the application of the analogy of legislation is impossible), can contribute to filling of gaps in PILA. ${ }^{24}$

Under the rules of analogy, one can assume that the legal gaps in conflict of laws rules applicable to the relationships arising out of inheritance contracts can be overcome using the conflict of laws rules applicable to relationships of the same legal nature. Therefore, if the court, following the view of the majority, characterizes the relationships arising out of inheritance contracts as contractual, it will apply the conflict of laws rules of Arts. 43, 44, and 47 of PILA, which determine the law applicable to contractual obligations. ${ }^{25}$ The

23 CCU, Art. 626, para. 1.

24 Namely, Art. 10, para 9 of Civil Procedure Code of Ukraine provides that: 'If the disputable relationships are not regulated by legislation, the court applies the legislation, which regulates the relationships with similar content (analogy of legislation). In the absence of such legislation the court applies the general principles of legislation (analogy of law)'. See: Tsyvilnyi protsesualnyi kodeks Ukrainy, Vidomosti Verkhovnoi Rady Ukrainy (Bulletin of Verkhovna Rada of Ukraine) No. 48 item 436/2017. The Commercial Procedure Code contains very similar rules on the analogy but with a slight difference: it admits the application of the analogy of legislation if the relationships are regulated not only by legislation but also by business customs. See: Hospodarskyi protsesualnyi kodeks Ukrainy, Vidomosti Verkhovnoi Rady Ukrainy (Bulletin of Verkhovna Rada of Ukraine) No. 48 item 436/2017, Art. 11, para. 10.

25 These articles were drafted on the basis of the Rome Convention on the Law Applicable to Contractual Obligations. See: Dovhert, A., Dohovir u mizhnarodnomu pryvat- 
analysis of these rules shows that the parties to inheritance contracts can choose a law applicable to them. ${ }^{26}$ In the absence of such a choice, the inheritance contract is to be governed by the law, which has the closest connection with the contract. ${ }^{27}$ The latter is to be determined by the analysis of the essence of the contract and assessment of the circumstances of the case. ${ }^{28}$ If these actions do not clarify the law, which has the closest connection with the contract, it must be determined according to the law of the country where the party who is to effect the performance characteristic of the transaction has his or her (its) place of residence or location. ${ }^{29}$

Article 44, para. I of PILA, which determines the party who effects the characteristic performance for some types of contracts, does not mention inheritance contract, increasing the ambiguity of its conflict of laws regulation. This conclusion follows from the essence of the characteristic performance as the "performance for which the payment is due, i.e., depending on the type of contract, the delivery of goods, the granting of the right to make use of an item of property, the provision of a service, transport, insurance, banking operations, security, etc.. ${ }^{30}$ However, under the inheritance contract, is it not very easy to determine for which party's performance 'the payment is due'. One might consider that it is a transferor's performance because a transferee pays for the acquisition of the estate of the transferor (in advance) by fulfilling his or her dispositions (e.g., by granting him or her services for cleaning his or her house or for personal care). In contrast, a transferee's performance can also be considered as characteristic because one might suggest that it is a transferor, who pays for the services of a transferee, determined by his or her dispositions, by granting him or her ownership for the estate upon his or her death.

This weak point of the concept of characteristic performance has been mentioned by some authors. ${ }^{31}$ It was also emphasized by the European Parliament and

nomu pravi (Contract in International Private Law) in Dovhert, A. S.; Kysil, V. I. (eds.), Mizhnarodne Pryvatne Pravo: pidruchnyk (International Private Law: Handbook), Alerta, Kyiv, 2014, p. 429.

26 PILA, Art. 43.

27 This conclusion follows from Arts. 44 and 32 of PILA.

28 PILA, Art. 32, para.3.

29 PILA, Art. 32, para. 3.

30 Guiliano, M.; Lagarde, P., Council Report on the Convention on the Law Applicable to Contractual Obligations, OJ C 282, 31 October 1980, p. 20.

31 Lipstein, K., Characteristic Performance - A New Concept in the Conflict of Laws in Matters of Contract for the EEC, Northwestern Journal of International Law and Business, vol. 3, 1981, pp. 409-410. 
the Council in the Proposal on Rome I Regulation, which mentions the contracts 'involving mutual performance by the parties in terms that can be regarded as characteristic on both sides'. ${ }^{32}$ It is recognized that, for such contracts, it 'may be difficult or even impossible to determine the characteristic performance. ${ }^{33}$

Additionally, it should be mentioned that Art. 44, para. 1 of PILA does not allow for determining a law applicable to inheritance contracts, under which both spouses act as a transferor if one of them has his or her place of residence in one state and the other in another state. The law which has the closest connection with an inheritance contract, under which a transferee acquires ownership of the transferor's immovable property or assets subject to state registration, is determined in another way: under a special rule of Article 44, para. I of PILA. This paragraph provides that the law, which has the closest connection with the contract, is the law of the state where immovable property is located or the law of the state where the state registration of the assets took place.

The scope of the law applicable to the contract covers its validity (except formal validity) and the consequences of invalidity, interpretation, rights and obligations of the parties, performance of the contract and the consequences of non-performance and termination. ${ }^{34}$ Formal validity of the contract should comply with the requirements of the law applicable to the substance of the transaction. However, a transaction is valid if it satisfies the formal requirements of the law of the country where the transaction has been concluded. If the contract has been concluded between persons who reside (or are located) in different countries, it is formally valid if it satisfies the formal requirements of the

32 Proposal for a Regulation of the European Parliament and the Council on the law applicable to contractual obligations (Rome I), COM (2005) 650 final, 15 December 2005, p. 6.

33 Wilderspin, M., The Rome I Regulation: Communitarisation and Modernisation of the Rome Convention, ERA Forum, vol. 9, issue 2, 2008, p. 265. The difficulty of ascertainment of characteristic performance was one of the reasons for the abolishment of application of this concept to the determination of law applicable to contractual obligations, suggested by the Commission of European Communities. See Proposal (fn. 32), p. 5. Although the concept of 'characteristic performance' has not totally disappeared from Rome I Regulation, it has become less important and according to its Article 4 (2) may be applied only subsidiary if the contract does not come within any type of contract mentioned in Article 4 (1) of the Regulation or if it combines the elements of different contracts, specified in Article 4 (1). See Bělohlávek, A., Rome Convention - Rome I Regulation Commentary: New EU Conflict-Of-Laws Rules For Contractual Obligations, Vol. 1, Juris Publishing, Huntington, New York, 2010, pp. 788, 790.

34 PILA, Art. 47. 
law of the place of the offeror's residence (location), unless otherwise provided by the contract. ${ }^{35}$ At the same time, the form of the transactions concerning immovable property is governed by the law of the state where it is located; the form of transactions concerning immovable property, the rights to which have been registered in Ukraine, is regulated by Ukrainian law. ${ }^{36}$

The characterization of the relationships arising out of inheritance contracts as successional ${ }^{37}$ leads to the determination of applicable law under the rules of Articles 70 or 71 of PILA. Under the general rule stipulated by Article 70, the succession relations are governed by the law of the state where the deceased (a transferor) had his or her last place of residence. ${ }^{38}$ However, since Ukraine follows a dualistic approach in conflict of laws regulations for succession, the law applicable to the inheritance contract, which concerns immovable property or assets, subject to state registration in Ukraine, is determined under the special rules of Article 71 of PILA. It provides lex loci rei sitae for succession of immovable property and the law of Ukraine for the assets subject to state registration in Ukraine.

PILA does not clarify the scope of the law applicable to succession relations. In doctrine, it is determined as 'succession as a whole'. ${ }^{39}$ However, the issues of capacity to make and revoke a will, as well as the form of the will and the act of its revocation, are not covered by lex successionis because PILA contains a special Article 72 concerning them. According to this article, the capacity to

35 PILA, Art. 31.

36 Under Article 181 of CCU the law can extend the regime of immovable property to the air, sea, inland navigation vessels, space objects and other things, and the rights which are subject to state registration.

37 This model of conflict of laws regulation will also be applied to all contracts in the succession law sphere, the legal nature of which is considered successional.

38 There is no explanation of the term 'last place of residence of the deceased' in PILA or other acts of Ukrainian legislation. There are several interpretations of this term in case law for the purposes of the application of the rules of CCU. However, these and doctrinal interpretations of this term are controversial. See Dikovska, I., Laws Applicable to Succession Relations Under Ukrainian Private International Law: Current State and Perspectives, Harmonius: Journal of Legal and Social Studies in South East Europe, no. 7, 2018, pp. 368-372, https://www.harmonius.org/wp-content/uploads/2018/12/Harmonius-2018.pdf (15.2.2019). From our point of view, 'last place of residence of the deceased' means a state, which was the centre of the vital interests of the deceased before his or her death, in which he lived with an intention of permanent living and where the main part of his or her assets is located. Bulletin ), no. 3, 2013, p. 144. 
make or revoke a will, its form and acts of revocation are governed by the law of the state where the deceased had his or her permanent place of residence ${ }^{40}$ at the time of making an act or at the time of death. Nevertheless, the will or act of its revocation cannot be invalidated because of non-observance of the form requirements, if the form complies with the requirements of the law where the will was made, the law of the state of citizenship or the law of the state of habitual residence of a deceased at the time of the act or at the time of death; or the law of the state where the immovable property is located. ${ }^{41}$

Since the inheritance contract is not a will, it is difficult to predict whether a court would decide to apply the rules of Article 72 of PILA regarding the capacity to conclude it and its form or would choose to use general conflict of laws rules of Articles 18 and 31 of PILA applicable to the civil capacity of natural persons and to the form of all transactions, respectively. However, it might be suggested that the court will apply the rules of Article 72 of PILA by analogy because the rules of this article are special and applicable to one of the possible dispositions upon death (wills), compared to the general rules of Articles 18 and 31 of PILA, which are applicable to all transactions. ${ }^{42}$

40 PILA does not explain the term 'permanent place of residence the deceased' used in Art. 72. There are several interpretations of this notion in the doctrine. See Dikovska, I., op. cit. (fn. 38), pp. 368-372. In our opinion, to determine 'permanent place of residence of the deceased', one should analyse the same factors as for the determination of the 'last place of residence of the deceased'. See, op. cit. (fn. 38). However, to determine 'permanent place of residence of the deceased at the time of making the act', one should learn the respective circumstances of the case at that time. The method of determination of the 'permanent place of residence of the deceased at the time of death' should coincide entirely with the determination of the 'last place of residence of the deceased'.

41 The connecting factors of Art. 72 of PILA are similar to the connecting factors set by Art. 1 of the Convention of October 1961 on the Conflicts of Laws Relating to the Form of Testamentary Dispositions (hereinafter: the Hague Convention), which entered into a force for Ukraine on May 4, 2011, https://www.hcch.net/en/ instruments/conventions/status-table/?cid=40 (15.02.2018).

42 The principle Lex specialis derogat legi generali has been widely recognized in Ukrainian law. See, for example, Spasybo-Fatieieva, I., Koiliziia zahalnykh ta spetsialnykh norm (na trokh prykladakh sudovoi praktyky) (Collision of General and Special Rules (In Three Examples of Case Law)), Pryvatne pravo (Private Law), no. 1, 2013, pp. 166-175; Boiko, V., Zahalnoteoretychna kharakterystyka spetsialnoi pravovoi normy ta yii konkurentsii iz zahalnoiu normoiu (General Theoretical Characteristic of Special Legal Rule and Its Competition With General Rule), Chasopys Natsioanlnoho Universytetu 'Ostrozka akademiia'. Seriia 'Pravo' (Journal of National University 'Ostroh Academy'. Law Series), vol. 7, no. 1, 2013, pp. 1-13. 
Thus, the capacity to make or revoke an inheritance contract will be governed by the law of the state where the deceased had his or her permanent place of residence at the time of conclusion of the inheritance contract or at the time of his or her death. However, the places of the permanent residence of the deceased at the time of conclusion of the inheritance contract and at the time of his or her death might not coincide, which could result in uncertainty of conflict of the laws regulating this issue, which is why the EU rules and national legislation of some other countries suggest the application of only one connecting factor in this situation: the place of habitual residence of the deceased at the time of the act. ${ }^{43}$

In addition, it is unclear whether a court would, in solving a particular case, admit the choice of applicable law to the inheritance contract if it characterizes the relationships arising out of it as successional. If the court decides to apply to the inheritance contract conflict of laws rules applicable to wills, by analogy, it will admit the choice of law applicable to relations arising out of inheritance contracts, although this choice will be limited to the law of the state of the deceased's citizenship at the time of conclusion of the inheritance contract. However, the parties will not be able to choose a law applicable to the inheritance contract if, under the contract, a transferee acquires ownership of the transferor's immovable property (in case of the transferor's death). The law chosen by the parties of the inheritance contract will also not cover the capacity of conclusion of the inheritance contract and its form.

It can be assumed that, in cases in which both spouses who have different citizenship act as a transferor, the choice of law of the state of citizenship of one of them will be admissible.

\section{CHARACTERIZATION OF THE AGREEMENTS AS TO SUCCESSION IN SR}

Although reference to the national concepts, while interpreting the rules of European PIL in some cases, is admissible ${ }^{44}$, the autonomous characterization

43 This conclusion follows from Articles 24 and 26 of SR (for the capacity of the making of wills) and from Articles 25 and 26 (for the capacity of conclusion of agreements as to succession). See also Civil Code of the Republic of Kazakhstan, Special part, I July 1999. № 409-1, was amended by the 2012, Art. 1122, https:// online.zakon.kz/Document/?doc_id=1049893 (2.11.2018).

44 Bariatti, S., Classification (Characterization) in Basedow, J.; Rühl, G.; Ferrari, F.; de Miguel Asensio, P. (eds.), Encyclopedia of Private International Law, Vol. 1, Edward Elgar Publishing, Cheltenham, 2017, p. 362. 
is 'highly recommended, even mandatory" ${ }^{245}$ in regard to the notions that determine the scope of application of the particular instrument. ${ }^{46}$ In addition, one can observe different approaches in the national legal systems of the Member States to the regulation of agreements as to succession. ${ }^{47}$ Therefore, SR gives its own definition of an agreement as to succession as 'an agreement, including an agreement resulting from mutual wills ${ }^{48}$, which, with or without consideration, creates, modifies or terminates rights to the future estate or estates of one or more persons party to the agreement'. ${ }^{\prime} 9$

The commentators point out the broad meaning of the agreement as to succession in SR, which exceeds the bounds of understanding of such agreements in national law. ${ }^{50}$ In other words, the agreement as to succession under SR is not identical to contractual dispositions upon death provided by the national law of a particular Member State. The definition of Art. 3 (l) (b) of SR allows for including 'agreements as to succession', contracts of inheritance, dispositions upon death in marriage agreements and other similar legal constructions provided by the laws of different Member-States. ${ }^{51}$

Some of the commentators have recognized the contractual nature of such agreements and have explained their inclusion in the scope of SR (and exclusion from the scope of Rome I Regulation consequently) because they 'affect successions'. ${ }^{52}$ Others have emphasized the binary nature of the agreement as to succession, as 'on one hand, it has elements of an agreement, while on the

45 Ibid., p. 363.

46 Ibid.

47 Helms, T., Contracts of Inheritance and Joint Wills, in Basedow, J.; Hopt, K. J.; Zimmermann, R. (eds.), The Max Planck Encyclopedia of European Private Law, Vol. I, Oxford University Press, Oxford, 2012, pp. 389-390.

48 The mutual wills are made by 'mutual testators', who 'each leave their property, usually to the other, on the condition that the second to die will necessarily then leave their estate ... to an agreed third party'. Sawyer, C.; Spero, M., Succession, Wills and Probate, Routledge, London, 2015, p. 106.

49 SR, Article 3, para. 1, letter b.

50 Fischer-Czermak, C., Artikel 25. Erbverträge in Deixler-Hubner, A.; Schauer, M. (eds.), Kommentar zur EU-Erbrechtsverordnung (EuErbVO), Manz'sche Verlags - und Universitätsbuchhanlung, Wien, 2015, p. 236.

51 See Rodrigo, J. R., Article 25 Agreements as to Succession in Calvo Caravaca, A. L.; Davì, A.; Mansel, H. P. (eds.), SR Commentary, Cambridge University Press, Cambridge, 2016, pp. 382-386.

52 Ibid., p. 382. 
other hand, due to its particular content ... and its aim ... it has the nature of a disposition of property upon death'.53

We support the idea that an agreement as to succession, covered by SR, has a binary nature and combines successional and contractual elements. The argument justifying its successional nature is that SR includes it in the 'disposition of property upon death', together with wills and joint wills. ${ }^{54}$ The contractual element is obvious since SR underscores that it is an 'agreement'. Although it does not define this term, comparative research has shown that most often it is used to specify a category of contract or a bilateral expression of consent. ${ }^{55}$

In comparison, the term 'will' (which is also not defined in SR) ${ }^{56}$ relates 'to unilateral legal acts by which a person expresses his or her last will concerning his or her succession'.57

Thus, it can be concluded that SR distinguishes between: 1. contractual dispositions upon death, which, to be concluded, need bilateral expression of consent of the person(s) who make(s) a disposition and the person(s) whose rights concerning the future estate are created, modified or terminated by this disposition (agreements as to succession); and 2. unilateral dispositions upon death, which, to be made, need the expression of the will only of the person(s) whose estate will be transferred to the person(s) defined in this disposition after his (her, their) death. This type of disposition includes wills and joint wills.

As a result, SR sets different articles containing conflict of laws rules for wills and joint wills (Article 24) and agreements as to succession (Article 25). Notably, Article 3, para. 1, letter 'b' of SR includes mutual wills in the scope of

53 Zoumpoulis, C., Article 25-Agreements as to Succession, in Pamboukis, H. P. (ed.), SR No 650/2012: A Commentary, Nomiki Bibliothiki, C. H. BECK, Hart Publishing, Nomos, Athens, München, Oxford, Baden-Baden, 2017, p. 297.

54 SR, Art. 3, para. 1, letter 'd'.

55 Tenenbaum, A.; Chainais, C.; Guilaume G.; Chénedé, F.; Perfumi, C.; Popova, I.; Riehm, T., Part I: Terminology. Chapter 1: Contract in Fauvarque-Cosson, B.; Mazeaud, D. (eds.), European Contract Law. Materials for a Common Frame of Reference: Terminology, Guiding Principles, Model Rules, Association Henri Capitant des Amis de la Culture Juridique Française and Société de Législation Comparée, Sellier. European Law Publishers, Munich, 2008, p. 17, https://www.legiscompare.fr/web/IMG/ pdf/CFR_I-XXXIV_1-614.pdf (2.11.2018).

56 The term 'joint will' is determined to be 'a will be drawn up in one instrument by two or more persons'. SR, Art. 3, para. 1, letter 'c'.

57 Weller, M., Article 3 - Definitions in Calvo Caravaca, A. L.; Davì, A.; Mansel, H. P. (eds.), SR Commentary, Cambridge University Press, Cambridge, 2016, p. 118. 
Article 25 and not of Article $24 .^{58}$ The reason for this difference is that, unlike other types of wills, mutual wills are in essence agreements. ${ }^{59}$ They may not be revoked unilaterally. ${ }^{60}$

Some authors have classified as dispositions upon death, governed by Article 25 of SR, not only agreements as to succession and mutual wills but also 'some joint wills ${ }^{61}$, donations conditional upon death, shared gifts, anticipated renunciations, as reductions, proprietary estoppels, in fact, all the acts creating obligations to be met by the estate of the future deceased'. ${ }^{62}$ However, other commentators have considered that, although Article 25 includes all agreements which have as a common element an agreement with regard to a future succession'63, it does not include joint wills in the scope of Article 25 because they are covered by Article 24 of SR. ${ }^{64}$

We agree with the latter point of view since a joint will is a type of unilateral disposition upon death and thus is governed by Article 24 of SR, which sets conflict of laws rules for unilateral dispositions upon death.

Therefore, it can be concluded that the agreements as to succession covered by SR have the following features: 1 . they require bilateral expression of consent of their parties to be concluded; 2. they transfer the estate upon the death of a person $^{65}$ and therefore take effect upon death, although 'some of their effects

58 Metallinos, A., Article 24. Dispositions of Property upon Death Other than Agreements as to Succession in Pamboukis, H. P. (ed.), SR No 650/2012: A Commentary, Nomiki Bibliothiki, C. H. BECK, Hart Publishing, Nomos, Athens, München, Oxford, BadenBaden, 2017, p. 285.

59 Kerridge, R., The Law of Succession, Sweet and Maxwell, London, 2009, p. 112.

60 Sloan, B., Borkowski's Law of Succession, Oxford University Press, Oxford, 2017, p. 58.

${ }_{61}$ Namely, the joint wills that contain an agreement. Lagarde, P., Article 24 in Bergquist, U.; Damascelli, D.; Frimston, R.; Lagarde, P.; Odersky, F.; Reinhartz, B., EU Regulation on Succession and Wills Commentary, Verlag Dr. Otto Schmidt KG, Köln, 2015, p. 144.

62 Lagarde, P., Article 25 in Bergquist, U.; Damascelli, D.; Frimston, R.; Lagarde, P.; Odersky, F.; Reinhartz, B., EU Regulation on Succession and Wills Commentary, Verlag Dr. Otto Schmidt KG, Köln, 2015, p. 148.

63 Zoumpoulis, op. cit. (fn. 53), p. 302.

64 Ibid.

65 Rodrigo, J. R., Article 25 Agreements as to Succession in Calvo Caravaca, A. L.; Davì, A.; Mansel, H. P. (eds.), SR Commentary, Cambridge University Press, Cambridge, 2016, p. 381; See also Bauer, F., Artikel 25 EuErb VO in Dutta, A.; Weber, J. (eds.), Internationales Erbrecht: EuErbVO, Erbrechtliche Staatsverträge, EGBGB, IntErbRVG, IntErbStR, IntSchenkungsR, C. H. BECK, München, 2016, p. 205. 
take place when they are drawn up;; ${ }^{66}$ and 3. they concern the estate of a person party to the agreement. ${ }^{67}$ (Consequently, the agreements between two persons concerning the estate of third persons are excluded from the scope of SR. ${ }^{68}$

\section{LAW APPLICABLE TO AGREEMENTS AS TO SUCCESSION UNDER SR}

\subsection{General remarks}

First, it should be noted that SR follows the monistic system of conflict of laws regulation of succession relations ${ }^{69}$ and thus does not provide for any special conflict of laws rules applicable to the succession of immovable property.

Second, it should be noted that Article 25, applicable to agreements as to succession, mentions only admissibility, substantive validity, binding effects between the parties, and conditions for dissolution of agreements as to succession among the issues covered by it, which is why the commentators conclude that other matters included in the scope of succession law by Article 23 are governed by lex successionis, determined by Articles 21 and 22. ${ }^{70}$ However, it should be noted that some issues covered by Article 23 will not arise in the context of the agreements as to succession. For instance, the sharing out of the estate (Article 23, para. 2, letter ' $j$ '), which usually occurs under a special contract between the heirs or under a court decision ${ }^{71}$, does not address with agreements as to succession.

66 Rodrigo, op. cit. (fn. 65), p. 382.

67 Nikolaidis, G., Article 3-Definitions, in Pamboukis, H. P. (ed.), SR No 650/2012: A Commentary, Nomiki Bibliothiki, C. H. BECK, Hart Publishing, Nomos, Athens, München, Oxford, Baden-Baden, 2017, p. 97; Zoumpoulis, op. cit. (fn. 53), p. 302.

68 Nikolaidis, G., op. cit. (fn. 67), p. 97.

69 Pamboukis, H.; Sivitanidis A. P., Article 21. General Rule in Pamboukis, H. P. (ed.), SR No 650/2012: A Commentary, Nomiki Bibliothiki, C. H. BECK, Hart Publishing, Nomos, Athens, München, Oxford, Baden-Baden, 2017, p. 204; Weber, J., Einleitung in Dutta, A.; Weber, J. (eds.), Internationales Erbrecht: EuErbVO, Erbrechtliche Staatsverträge, EGBGB, IntErbRVG, IntErbStR, IntSchenkungsR, C. H. BECK, München, 2016, p.14.

70 Zoumpoulis, op. cit. (fn. 53), p. 306.

71 Metallinos, A., Article 23. The Scope of the Applicable Law in Pamboukis, H. P. (ed.), SR No 650/2012: A Commentary, Nomiki Bibliothiki, C. H. BECK, Hart Publishing, Nomos, Athens, München, Oxford, Baden-Baden, 2017, p. 279. 
Therefore, from Article 23, one can conclude that the rules of Articles 2122 will be applied to the following issues arising in connection with agreement as to succession: the causes, the time and place of the opening of succession ${ }^{72}$; the circle of beneficiaries of an estate and their shares, obligations, succession rights $^{73}$; the capacity to be a contractual heir ${ }^{74}$; the disinheritance ${ }^{75}$ and disqualification ${ }^{76}$ of the contractual heir or legatee by his or her conduct; the transfer to

72 Art. 23, para. 2, letter 'a' of SR. The commentators point out that, under the laws of all countries, the cause of the opening of succession is the physical death of a person. Death, recognized by a court in cases of disappearance of a person, can also constitute grounds for the opening of inheritance. See Schmidt, J., Artikel 23 EuErb VO in Dutta, A.; Weber, J. (eds.), Internationales Erbrecht: EuErbVO, Erbrechtliche Staatsverträge, EGBGB, IntErbRVG, IntErbStR, IntSchenkungsR, C. H. BECK, München, 2016, p. 177. In terms of the agreement as to succession, the opening of inheritance leads to taking of effect of the provisions mortis causa, e.g., those that stipulate the transfer of the estate, provided by the agreement, to the contractual heir.

73 The agreement as to succession determines the beneficiaries of an estate and their duties and rights. Thus, it might change the circle of the intestate beneficiaries. Depending on the applicable law, the rules regarding the reserved portion might or might not spread to the agreement as to succession. Consequently, lex successionis determines the legal impact of the agreement as to succession on the circle of beneficiaries and their shares.

74 Article 23, para. 2, letter 'c' of SR uses the wording 'the capacity to inherit', which in terms of the agreement as to succession means the capacity to be a contractual heir.

75 SR, Art. 23, para. 2, letter 'd'. Disinheritance is interpreted by commentators to mean deprivation of a reserved portion due to the conduct of the descendant, which is provided, for example, by Art. 848 of Spanish Civil Code or $\S 2333$ of German Civil Code (hereinafter: BGB) (such as an attempt on the life of the testator or a person close to him or her; intentional violation of obligations to maintain the testator; and so on). See Schmidt, J., op. cit. (fn. 72), pp. 182-183. Other commentators have also noted that disinheritance concerns only heirs entitled to a reserved portion. See Metallinos, A., op. cit. (fn. 7l), p. 263. Thus, in terms of the agreement as to succession, disinheritance could occur only if a contractual heir is someone entitled to a reserved share.

76 As an example of the rule, which provides for disqualification, J. Schmidt mentioned § 2345 of BGB. See Schmidt, J., op. cit. (fn. 72), p. 183. This paragraph regulates not only unworthiness to receive a reserved portion but also unworthiness to receive a legacy. However, below, J. Schmidt states that disqualification concerns all types of conduct due to which a person can lose his (her) inheritance rights under all national laws. See Schmidt, J., op. cit. (fn. 72), p. 183. Other commentators also do not restrict the circle of persons, whose disqualification is mentioned in Art. 23, para. 2, letter 'd', by those entitled to a reserved share. See Metallinos, A., op. cit. (fn. 71), pp. 262-263. Therefore, it can be concluded that, unlike disinheritance, disqualification concerns all persons who have inheritance rights regardless of whether they are entitled to a reserved portion. 
the contractual heir and to the legatee (if the agreement includes a legacy) of the assets, rights and obligations forming the part of estate specified by the agreement; the terms and consequences of the acceptance or waiver of the succession or legacy provided by the agreement; the powers of the contractual heir or administrator of estate concerning the sale of property and payment of creditors (however, this issue can also be governed by lex fori, "where the law applicable to succession does not provide for sufficient powers to preserve the assets of an estate or to protect the rights of the creditors or of the persons ${ }^{777}$, or if lex successionis is a law of a third state ${ }^{78}$; the liability of the contractual heir for the debts of the estate ${ }^{79}$; the part of the estate concerning which the testator can conclude an agreement as to succession; whether the rules on reserved shares and other restrictions on the disposal of property extend to the agreement as to succession's restrictions on the testator's freedom to dispose of property upon death by conclusion of the agreement as to succession ${ }^{80}$; and whether the rules on restoration and accounting for gifts, advancement or legacies should be applicable to the estate subject to the agreement as to succession when determining the shares of different beneficiaries.

The formal validity of the agreements as to succession is also excluded from the scope of Article 25. For written agreements, it is determined according to Article 27. The formal validity of oral agreements as to succession is not regulated by SR. ${ }^{81}$

77 SR, Art. 29, para. 2.

78 SR, Art. 29, para. 3.

79 SR, Art. 23, para. 2, letter 'g' does not specify the circle of persons whose liability for the debts shall govern lex successionis. Depending on applicable law it can include heirs, legatees or administrators. See Lagarde, P., Article 23, in Bergquist, U.; Damascelli, D.; Frimston, R.; Lagarde, P.; Odersky, F.; Reinhartz, B., EU Regulation on Succession and Wills Commentary, Verlag Dr. Otto Schmidt KG, Köln, 2015, p. 139; Schmidt, J., op. cit. (fn. 72), p. 192. In terms of the agreement as to succession, it means that lex successionis governs whether the contractual heir is liable for the debts of the estate.

According to the commentators, the mentioning of the 'disposable part of the estate' in Art. 1, para. 2, letter ' $h$ ' of SR, means that rules of lex successionis distinguish between the disposed and reserved parts of the estate. See Metallinos, A., op cit. (fn. 71), p. 271. Thus, provision of Art. 1, para. 2, letter ' $h$ ' of SR addresses the most important restrictions on testamentary freedom: the rights of the persons close to testators regarding their shares of estates. See Schmidt, J., op. cit. (fn. 71), p. 193. Therefore, in general it can be concluded that, under Art. 1, para. 2, letter ' $h$ ' of $\mathrm{SR}$, lex successionis governs the restrictions of the testator's freedom to dispose of property upon death by conclusion of the agreement as to succession. 


\subsection{Conflict of laws rules of Article 25 of SR}

It deserves mentioning that the draft of SR did not specify concrete issues covered by the law applicable to agreements as to succession. ${ }^{82}$ Highlighting only admissibility, substantive validity and binding effects of the agreement between parties, the conditions for dissolution of the agreements as to succession among the issues in Article 25 occurred due to the initiative of the Max Planck Institute for Comparative and Private International Law, researchers from which pointed out the ambiguity of wording 'agreement ... governed by law' in the article aimed at conflict of laws regulation for agreements as to succession and the problems that it can cause. ${ }^{83}$

In general, the concept of admissibility of disposition upon death answers the question of what types of these dispositions can be validly asserted ${ }^{84}$ In terms of the agreement as to succession it is determined as 'the possibility to conclude an agreement'. ${ }^{85}$ The admissibility of the agreement as to succession includes any restrictions on the parties of such agreements and assets that can be transferred under it. ${ }^{86}$ Article 25, para. 2 separates the admissibility of the agreement as to succession from its substantive validity. This distinction is explained by the differences in approaches of the Member States regarding the characterization of the prohibition to conclude agreements as to succession. In some of them, it is considered a matter of substance and in others a matter of form. ${ }^{87}$ Thus, the wording of Art. 25, para. 2 allows for avoiding discussion of whether the admissibility of the agreement as to succession should be determined

82 The European Commission's Proposal for a Regulation of the European Parliament and of the Council on jurisdiction, applicable law, recognition and enforcement of decisions and authentic instruments in matters of succession and the creation of a European Certificate of Succession, COM (2009) 0154 final, Art. 18.

83 Basedow, J.; Dutta, A.; Bauer, C.; Beckhaus, G.; Damar, D.; Fornasier, M.; et al., Comments on the European Commission's Proposal for a Regulation of the European Parliament and of the Council on jurisdiction, applicable law, recognition and enforcement of decisions and authentic instruments in matters of succession and the creation of a European Certificate of Succession, Rabels Zeitschrift für ausländisches und internationales Privatrecht, vol. 74, no. 3, 2010, p. 617.

84 Bauer, F., Artikel 24 EuErb VO in Dutta, A.; Weber, J. (eds.), Internationales Erbrecht: EuErbVO, Erbrechtliche Staatsverträge, EGBGB, IntErbRVG, IntErbStR, IntSchenkungsR, C. H. BECK, München, 2016, p. 204.

85 Zoumpoulis, C., op. cit. (fn. 53), p. 307.

86 Rodrigo, J. R., op. cit. (fn. 65), p. 392.

87 Zoumpoulis, C., op. cit. (fn. 53), pp. 307-310. 
under the connecting factors, which are applicable to the formal validity of the agreement as to succession or to substantive validity.

The elements of the substantive validity of the agreements as to succession are determined by Article 26. They include the issues usually associated with the substantive validity of dispositions upon death: the capacity to make them; the causes barring the person from making the disposition in favour of certain persons or from receiving succession property from the person making the disposition; the admissibility of representation while making the disposition upon death; questions relating to the consent or intention of the person making the disposition. At the same time, the interpretation of the dispositions upon death, which is recognized as a question of fact ${ }^{88}$, is also considered one of the issues constituting the substantive validity of the dispositions upon death for the purposes of SR.

The inclusion of 'binding effects between the parties' is one of the characteristics of the scope of law applicable to agreements as to succession under Article 25. It cannot be found in the scope of Article 24, which is applicable to unilateral dispositions upon death. The insertion of this issue into the scope of Article 25 is explained, on the one hand, by the contractual nature of agreements as to succession. On the other hand, it is convenient to regulate the admissibility, substantial validity and binding effects of agreements as to succession by the law of one state; otherwise, it can result in annulment of the agreement. ${ }^{89}$

Agreements as to succession of one person and several persons can be governed by different conflict of laws rules. ${ }^{90}$ In the case of agreement aimed at the succession of one person, the law applicable to its admissibility, substantive validity and binding effects, including the conditions of its dissolution, is determined as the law 'that, under this Regulation would have been applicable to the succession if he or she had died on the day on which the agreement was concluded'. ${ }^{91}$ This sentence means that these issues may be governed by the law of the state where the deceased had his or her habitual place of residence ${ }^{92}$; in

88 Zoumpoulis, C., Article 26. Substantive Validity of Dispositions of Property upon Death, in Pamboukis, H. P. (ed.), SR No 650/2012: A Commentary, Nomiki Bibliothiki, C. H. BECK, Hart Publishing, Nomos, Athens, München, Oxford, Baden-Baden, 2017, p. 331; Lagarde, P., Article 26 in Bergquist, U.; Damascelli, D.; Frimston, R.; Lagarde, P.; Odersky, F.; Reinhartz, B., EU Regulation on Succession and Wills Commentary, Verlag Dr. Otto Schmidt KG, Köln, 2015 , p. 153.

Zoumpoulis, C., op. cit. (fn. 53), p. 313.

SR, Article 25, paras. 1 and 2, respectively.

Ibid., Article 25, para. 1.

Ibid., Article 21, para. 1. 
exceptional cases, by the law of the state with which he or she was manifestly more closely connected on the day of the conclusion of the agreement ${ }^{93}$; or by the law of the state whose nationality he or she possessed at the time of conclusion of the agreement or at the time of his or her death, if he or she exercises his or her right to choose the applicable law. ${ }^{94}$

In connection with the escape clause, provided by Article 21, para. 2, commentators have emphasized both the advantages of its application (namely it creates the possibility of overcoming the inflexibility of conflict of laws rules) and the disadvantages (for instance, the relative uncertainty to which it leads). ${ }^{95}$ They have also pointed out the limited meaning of the manifestly closer tie because the place of vital interests of the deceased cannot be used in this case since, in terms of SR, the place of vital interests is the habitual residence of the deceased ${ }^{96}$ However, the application of the law, which is 'manifestly more closely connected with the deceased', provided by Art. 21, para. 2, is a consequence of refusal to apply the connecting factor 'habitual residence of the deceased', which means that the law of the state with which the deceased was more closely connected is not the state of his or her vital interests. As an example of the application of the law of the state with which the deceased was more closely connected, instead of the law of the state of his (her) habitual residence, Recital 25 of the Preamble to SR and commentators mention the situation in which the change of the place of habitual residence is very recent. ${ }^{97}$

Some commentators have called the escape clause, provided by Article 21, para. 2 'surprising, debatable and dangerous. ${ }^{98}$ In particular, its debatableness is explained in two ways. First, the fullness and casuistic character of the habitual residence concept, used in SR, eliminates the need to include any escape clause

93 Ibid., Article 21, para. 2.

94 Ibid., Article 22, para. 1.

95 Pamboukis, H.; Sivitanidis A. P., op. cit. (fn. 69), p. 208.

96 Ibid. See also SR, Preamble, Recital 24.

97 Bauer, F., Artikel 21 EuErb VO in Dutta, A.; Weber, J. (eds.), Internationales Erbrecht: EuErbVO, Erbrechtliche Staatsverträge, EGBGB, IntErbRVG, IntErbStR, IntSchenkungsR, C. H. BECK, München, 2016, p. 166; Lagarde, P., Article 21 in Bergquist, U.; Damascelli, D.; Frimston, R.; Lagarde, P.; Odersky, F.; Reinhartz, B., EU Regulation on Succession and Wills Commentary, Verlag Dr. Otto Schmidt KG, Köln, 2015, p. 125; Pamboukis, H.; Sivitanidis A. P., op. cit. (fn. 69), p. 208.

98 Calvo Caravaca, A. L., Article 21. General Rule, in Calvo Caravaca, A. L.; Davì, A.; Mansel, H. P. (eds.), SR Commentary, Cambridge University Press, Cambridge, 2016, p. 317. 
in it. ${ }^{99}$ Second, in succession relations regulation 'the essential issue is not that of giving a more suitable location to a specific obligation, rather of deciding the fate of all assets'. ${ }^{100}$

It also should be noted that the commentators' attitudes towards the possibility of choosing the applicable law to the admissibility, substantive validity and binding effects of the agreement as to succession between two alternatives (the law of the state whose nationality the deceased possesses at the time of making the choice or at the time of his or her death) differs. While some of them have welcomed $i^{101}$, others, although admitting such a possibility, have offered to deprive the deceased the right to choose the law of his or her future nationality (at the time of death) since it is unknown at the time of the agreement. ${ }^{102}$ The second theory should be supported especially because the circle of issues concerning which the deceased can choose his or her future law includes the binding effect of the agreement between the parties.

The right to choose the law applicable to the admissibility, substantive validity and binding effects, including the conditions of dissolution of the agreement as to succession, has a special feature compared with the right to choose applicable law to other matters of succession. It is not 'professio juris' in a strict sense of this term, which is usually understood as the choice of the applicable law, made by the deceased unilaterally ${ }^{103}$, as far as the parties should agree to this choice. ${ }^{104}$ The deceased can choose unilaterally the law of his or her nationality at the time of the agreement or at the time of death to the succession issues not covered by Article 25. ${ }^{105}$

If the agreement regulates the succession of several persons, the method of determination of the applicable law is more complicated and depends on the issue that must be governed. For instance, the admissibility of agreements as to succession concluded by several persons is determined as a result of cumulative

99 Ibid., pp. 318-319.

100 Ibid., p. 319.

101 Zoumpoulis, C., op. cit. (fn. 53), p. 318.

102 Rodrigo, J. R., op. cit. (fn. 65), pp. 387-388.

103 Ibid., p. 387.

104 Roodt, C., Party Autonomy in International Law of Succession: A Starting Point for a Global Consensus?, Tydsrif vir die Suid-Afrikaanse Reg, no. 2, 2009, p. 242; Li, H., Some Recent Developments in the Conflict of Laws Succession, Recueil Des Cours. Collected Courses of the Hague Academy of International Law, vol. 224, Brill, Nijhoff, Leiden, Boston, 1990, p. 65.

105 Rodrigo, J. R., op. cit. (fn. 65), p. 387. 
application of the laws of all states 'which, under this Regulation, would have governed the succession of all the persons involved if they died on the day on which the agreement was concluded'. ${ }^{106}$ The dependence of the agreement on the laws of several countries to which cumulative application leads is considered a disadvantage ${ }^{107}$ However, it can be overcome by the choice of law applicable to the admissibility of the agreements as to succession, provided by Article 25, para. 3 .

The law, applicable to the substantive validity, binding effects, and conditions for dissolution of the agreement as to succession concluded by several parties is determined as the law with which it has the closest connection (among all of the laws that govern the admissibility of such agreements). ${ }^{108}$

Among the factors that should be considered in determining the law which has the closest connection with the agreement as to succession concluded by several persons, commentators have mentioned the location of the greater part of the mutual assets of the estates of the parties to the agreement; the place of their last joint habitual residence ${ }^{109}$; the place where the agreement was made; and the nationalities of the parties. ${ }^{110}$

However, it should be noted that the application of the law which has the closest connection with the agreement as to succession to the admissibility of the agreement regarding succession of several persons has been criticized since it is indeterminate at the time of the agreement and thus leads to legal uncertainty. ${ }^{11}$

Third, SR permits the parties to choose the law applicable to the agreements as to succession. This choice is limited to 'the law which the person or one of the persons whose estate is involved could have chosen in accordance with Article $22 .{ }^{112}$ This statement means that the parties can choose the national law of one of the persons mentioned in the latter provision at the time of the agreement or at the time of death. ${ }^{113}$ It concerns only the admissibility, substantive validity, and binding effects between the parties of the agreements as to succession.

\footnotetext{
106 SR, Art. 25, para. 2, subpara. 1.

107 Zoumpoulis, C., op. cit. (fn. 53), p. 320.

108 SR, Art. 25, para. 2, subpara. 2.

109 Lagarde, P., op. cit. (fn. 62), p. 149.

110 Rodrigo, J. R., op. cit. (fn. 65), p. 391.

111 Zoumpoulis, C., op. cit. (fn. 53), p. 321.

112 SR, Art. 25, para. 3.

113 Lagarde, P., op. cit. (fn. 62), pp. 149-150.
} 
Article 22 also allows the deceased to choose his or her national law as applicable to succession as a whole, creating the possibility of choosing one national law for the admissibility, substantive validity, and binding effects between the parties of the agreements as to succession and succession as a whole. However, a choice of the applicable law regarding succession as a whole before conclusion of an agreement as to succession, without subsequent choice of the law applicable to the admissibility, substantive validity, and binding effects of the agreement, would lead to the application of different laws to the issues included in 'succession as a whole' (the determination of the beneficiaries, reserved shares, liability for the debts, etc.) and the admissibility, substantive validity and binding effects between the parties. ${ }^{114}$

Since the choice of applicability to the admissibility, substantive validity, and binding effects between the parties of the agreements as to succession should correspond to the conditions, set by Article 22, it can be expressed or tacit. ${ }^{115}$ According to Recital 39 of the Preamble, the latter exists 'where, for instance, the deceased had referred in his disposition to specific provisions of the law of the State of his nationality or where he had otherwise mentioned that law' (e.g., if a disposition mentions specific terms or institutions of the deceased's national law). ${ }^{116}$

\section{SHOULD PILA USE THE APPROACHES OF SR?}

The absence of conflict of laws rules applicable to an inheritance contract in PILA causes legal uncertainty, which is enhanced due to different approaches to the determination of the legal nature of this contact, resulting in unpredictability of its characterization by the court. Regardless of how the court would characterize the relationships arising out of the inheritance contract, both types of existing PILA conflict of laws rules (contractual or successional), which may be applied to this contract, can hardly be called effective. Therefore, there is a need to include in PILA conflict of laws rules that are applicable to inheritance contracts.

SR, which undoubtedly accumulates the latest developments in the field of conflict of laws regime of international succession relations, could serve as mod-

114 Zoumpoulis, C., op. cit. (fn. 53), p. 323.

115 Stamatiadis, D., Article 22-Choice of Law in Pamboukis, H. P. (ed.), SR No 650/2012: A Commentary, Nomiki Bibliothiki, C. H. BECK, Hart Publishing, Nomos, Athens, München, Oxford, Baden-Baden, 2017, pp. 230-233.

116 Ibid., p. 232. 
el for future rules of PILA, including the conflict of laws rules on inheritance contract because the latter has the features of an agreement as to succession, covered by SR. Conversely, SR contains some provisions that are estimated as controversial ${ }^{117}$, which is why adaptation of PILA to it should be carefully considered.

The research shows that the main features of conflict of laws regulations for agreements as to succession in SR are the following. 1. Its special conflict of laws rules, applicable to agreements as to succession, cover only the admissibility, substantive validity and binding effects of this agreement between the parties. They direct one to the 'the law which, under this Regulation, would have been applicable to the succession'. However, the rules of its determination depend not on the time of death but on the time when the agreement was concluded. From our point of view, such conflict of laws regulation of the agreement as to succession corresponds to its double legal nature: as a disposition upon death, on the one hand, and as an agreement, on the other hand. The determination of applicable law depending on the time of the conclusion of agreement (and not on the moment of death) is very important since the parties should certainly know whether the agreement is admissible at the time of its conclusion. At this time, they must also be aware of the rules that govern the substantive validity of the agreement and the binding effects between them, including the terms of its dissolution. Therefore, this approach of SR should be accepted by Ukrainian law.

2 . The agreement concerning the succession of several persons is admissible if it is admissible under lex successionis of all of these persons. Although this approach is not very convenient, we believe that it also should be adopted in Ukrainian law because non-admissibility of the agreement under the law of one of the persons who act as transferors will impede or preclude the execution of the agreement. Thus, it is necessary to know whether it is admissible under lex successionis of all of the persons who act as a transferor at the time of conclusion of the agreement.

3. The substantive validity and binding effects between the parties of the agreement as to succession of several persons are governed by the law with which they have the closest connection. This law is chosen among all of the laws that regulate its admissibility. This approach also deserves to be accepted. However, we cannot agree that such factors as the nationality of the parties, which has been offered by some commentators for the determination of law

117 Załucki, M., New Revolutionary European Regulation on Succession Matters. Key Issues and Doubts, Revista de Derecho Civil, vol. III, no. 1, 2016, pp. 165-176. 
which has the closest connection with the agreement as to succession ${ }^{118}$, should be considered in determining the law with the closest connection to the inheritance contract. It often happens in the modern world that people have been living in a state other than the state of their nationality for many years. In this case, nationality is not important since a person has lost touch with his or her homeland. However, even if the state of nationality and the state of permanent, long-term living coincide and even if this state is the place where the most important interests of the deceased are accumulated, the state of nationality could hardly have the closest connection with the agreement. Rather, it might have the closest connection with the deceased. For the same reason, the state of last joint habitual residence of the person ${ }^{119}$ also cannot be considered a factor for the determination of the state which has the closest connection with the inheritance contract: it can have the closest connection with the person who acts as a transferor but not with the contract.

The state where a greater part of the parties' mutual assets is located, suggested as one of the circumstances to be considered to determine the law, applicable to the agreement as to succession ${ }^{120}$, seems the most appropriate factor to determine the law with which an inheritance contract, admitted by Ukrainian law, is most closely connected. This conclusion follows from the main purpose $^{121}$ of the inheritance contract: 'to determine the legal fate of the assets of the transferor in case of his death'. ${ }^{122}$

The next factor that can be considered is the state where a transferee should fulfil the actions of a property or non-property character, as specified by a transferor. Although it is not mentioned among factors that should be considered for the determination of the law which has the closest connection with the agreement as to succession under SR, in our opinion, it is necessary to be considered for the determination of the law which has the closest connection with the inheritance contract under Ukrainian law because, unlike an agreement as to succession, which according to the Article 3 of SR is an agreement

118 Lagarde, P., op. cit. (fn. 62), p. 149; Rodrigo, J. R., op. cit. (fn. 65), p. 391.

119 Also offered as a factor in the determination of the closest connection of the agreement as to succession, see Lagarde, P., op. cit. (fn. 62), p. 149.

120 Rodrigo, J. R., op. cit. (fn. 65), p. 391.

121 However, we do not agree that it is a 'main purpose' of the inheritance contract since the fulfilment of the transferee's obligations is also very important. Rather, it is one of the main purposes of this contract.

${ }^{122}$ Kurylo, T., Osoblyvosti ukladennia spadkovoho dohovoru v tsyvilnomu pravi Ukrainy (The Main Features of the Conclusion of Inheritance Contract), Nashe pravo (Our Law), no. 6, 2015, p. 157. 
... with or without consideration', an inheritance contract provided by Article 1302 of CCU always requires consideration.

4. The parties of the agreement as to succession are allowed to choose a law applicable to its admissibility, substantive validity and binding effects between them. A transferor under the agreement may choose unilaterally a law applicable to all other issues connected to succession, covered by Article 23 of SR. In both cases, it may be the law of the state whose nationality a deceased (a transferor) possesses at the time of making a choice or at the time of death. In our opinion, PILA should also provide the parties with the opportunity to choose the law applicable to the inheritance contract. Making this choice should be allowed not only for issues of admissibility, substantive validity, and binding effects between the parties and conditions for its dissolution but also for all other issues connected with it (which, in SR, are covered by Article 23).

The approach of SR according to which a testator under the agreement as to succession can unilaterally choose a law applicable to the issues, covered by Article 23 of the EU Succession Regulation, seems inappropriate for conflict of laws regulation of the inheritance contract, known in Ukrainian law because the latter is a bilateral contract. However, since the inheritance contract is a disposition upon death, the parties' choice should be limited to the law of the state whose nationality a transferor possesses at the time of the choice. If, under the contract, both spouses, who possess different nationalities, act as a transferor, the parties should be allowed to choose the law of nationality of one of the spouses. Governing the inheritance contract to the law of the transferor's nationality at the time of death seems risky because as it might be difficult to predict it at the time of the agreement.

\section{CONCLUSION}

Unlike SR, PILA does not contain any special rules applicable to contractual dispositions upon death. In this situation, the law applicable to an inheritance contract (which is the only contractual disposition upon death known to Ukrainian law) may be determined either on the basis of conflict of laws rules applicable to contractual obligations or to inheritance relationships, depending on how the court decides the issue of the legal nature of the relationships arising out of the inheritance contract.

The use of conflict of laws rules applicable to contractual relations would lead to the conclusion that the relationships arising out of the inheritance contract may be governed either by the law chosen by the parties or, in the absence of such a choice, by the law which has the closest connection with the contract. 
The latter might be difficult to determine since the concept of characteristic performance in some cases will not be helpful for inheritance contracts. The inheritance contract, which provides the transfer of ownership to immovable property, will be governed by lex rei sitae. The law applicable to the form of the inheritance contract will be determined under the conflict of laws rules, applicable to all transactions. The application of the law where the deceased had his last place of residence will occur if the relationships arising out of the inheritance contract are characterized as successional. Whether the contract stipulates the transfer of ownership to immovable property, lex rei sitae will be applied. It is unclear what conflict of laws rules will be applied to the form of the inheritance contract: those applicable to wills or to transactions in general.

SR contains special conflict of laws rules applicable to the admissibility, substantive validity, binding effects between the parties, and conditions for dissolution of agreements as to succession. The parties are allowed to choose the law applicable to these issues. Other matters that might arise in connection with succession, mentioned in Article 23 of SR, are determined under the rules applicable to succession as a whole. SR does not distinguish between conflict of laws regulations for movable and immovable property. Most rules of SR concerning agreements as to succession should be accepted by Ukrainian legislation.

\section{BIBLIOGRAPHY}

Bariatti, S., Classification (Characterization) in Basedow, J.; Rühl, G.; Ferrari, F.; de Miguel Asensio, P. (eds.), Encyclopedia of Private International Law, Vol. 1, Edward Elgar Publishing, Cheltenham, 2017, pp. 358-365.

Basedow, J.; Dutta, A.; Bauer, C.; Beckhaus, G.; Damar, D.; Fornasier, M.; et al., Comments on the European Commission's Proposal for a Regulation of the European Parliament and of the Council on jurisdiction, applicable law, recognition and enforcement of decisions and authentic instruments in matters of succession and the creation of a European Certificate of Succession, Rabels Zeitschrift für ausländisches und internationales Privatrecht, vol. 74, no. 3, 2010, pp. 522-720.

Bauer, F., Artikel 21 EuErb VO in Dutta, A.; Weber, J. (eds.), Internationales Erbrecht: EuErbVO, Erbrechtliche Staatsverträge, EGBGB, IntErbRVG, IntErbStR, IntSchenkungsR, C. H. BECK, München, 2016, pp. 164-166.

Bauer, F., Artikel 24 EuErb VO in Dutta, A.; Weber, J. (eds.), Internationales Erbrecht: EuErbVO, Erbrechtliche Staatsverträge, EGBGB, IntErbRVG, IntErbStR, IntSchenkungsR, C. H. BECK, München, 2016, pp. 199-202. 
Bauer, F., Artikel 25 EuErb VO in Dutta, A.; Weber, J. (eds.), Internationales Erbrecht: EuErbVO, Erbrechtliche Staatsverträge, EGBGB, IntErbRVG, IntErbStR, IntSchenkungsR, C. H. BECK, München, 2016, pp. 203-209.

Bělohlávek, A., Rome Convention - Rome I Regulation Commentary: Commentary: New EU Conflict-Of-Laws Rules for Contractual Obligations, Vol. 1, Juris Publishing, Huntington, New York, 2010.

Boiko, V., Zahalnoteoretychna kharakterystyka spetsialnoi pravovoi normy ta yii konkurentsii iz zahalnoiu normoiu (General Theoretical Characteristic of Special Legal Rule and Its Competition With General Rule), Chasopys Natsioanlnoho Universytetu 'Ostrozka akademiia'. Seriia 'Pravo' (Journal of National University 'Ostroh Academy'. Law Series), vol. 7, no. 1, 2013, pp. 1-13.

Calvo Caravaca, A. L., Article 21. General Rule in Calvo Caravaca, A. L.; Davì, A.; Mansel, H. P. (eds.), SR Commentary, Cambridge University Press, Cambridge, 2016, pp. 298-322.

Civil Code of the Republic of Kazakhstan, Special part, I July, 1999. № 409-1, has been amended by the 2012, Art. 1122 https://online.zakon.kz/Document/?doc_id $=1049893$ (2.11.2018).

Convention of October 1961 on the Conflicts of Laws Relating to the Form of Testamentary Dispositions, which has entered into force for Ukraine on May, 4, 2011, https://www.hcch.net/en/instruments/conventions/status-table/?cid=40 (15.02.2018).

Guiliano, M.; Lagarde, P., Council Report on the Convention on the Law Applicable to Contractual Obligations, OJ C 282, 31 October 1980.

Dikovska, I., Laws Applicable to Succession Relations Under Ukrainian Private International Law: Current State and Perspectives, Harmonius: Journal of Legal and Social Studies in South East Europe, no. 7, 2018, pp. 368-372, https:// www.harmonius.org/wp-content/uploads/2018/12/Harmonius-2018.pdf (15.02.2019), pp. 362-375.

Dovhert, A., Dohovir u mizhnarodnomu pryvatnomu pravi (Contract in International Private Law) in Dovhert, A. S.; Kysil, V. I. (eds.), Mizhnarodne Pryvatne Pravo: pidruchnyk (International Private Law: Handbook), Alerta, Kyiv, 2014, pp. 427-438.

European Commission's Proposal for a Regulation of the European Parliament and of the Council on jurisdiction, applicable law, recognition and enforcement of decisions and authentic instruments in matters of succession and the creation of a European Certificate of Succession, COM (2009) 0154 final.

Fischer-Czermak, C., Artikel 25. Erbverträge in Deixler-Hubner, A.; Schauer, M. (eds.), Kommentar zur EU-Erbrechtsverordnung (EuErbVO), Manz'sche Verlags und Universitätsbuchhandlung, Wien, 2015. 
Helms, T., Contracts of Inheritance and Joint Wills in Basedow, J.; Hopt, K. J.; Zimmermann, R. (eds.), The Max Planck Encyclopedia of European Private Law, vol. I, Oxford University Press, Oxford, 2012, pp. 389-390.

Hospodarskyi protsesualnyi kodeks Ukrainy, Vidomosti Verkhovnoi Rady Ukrainy (Bulletin of Verkhovna Rada of Ukraine) No. 48 item 436/2017.

Kerridge, R., The Law of Succession, Sweet and Maxwell, London, 2009.

Krasytska, O., Perevahy ta ryzyky spadkovoho dohovoru (Advantages and Risks of an Inheritance Contract) in Kuznetsova, N.; Martynenko, I.; Borysova, V.; Maidanyk, R. (eds.), Problemy Tsyvilnoho Prava Ta Protsesu: tezy dopovidei uchasnykiv naukovo-praktychnoi konferentsii, prysviachenii pamiati O.A. Pushkina (Problems of Civil Law and Procedure: Abstracts of Reports of the Participants of the Scientific-Practical Conference, in Tribute to the Memory of O.A. Pushkin), KhNUVS, Kharkiv, 2017, pp. 102-106.

Kukhariev, O., Spadkove pravo Ukrainy (Succession Law of Ukraine), Alerta, Kyiv, 2013.

Kukhariev, O., Vykonannia spadkovoho dohovoru: notarialna ta sudova praktyka (The Performance of the Inheritance Contract: Notarial and Court Practice), Mala Entsyklopediia Notariusa (Small Encyclopedia of a Notary), vol. 89, no. 5, 2016, pp. 140-149.

Kurylo, T., Osoblyvosti ukladennia spadkovoho dohovoru v tsyvilnomu pravi Ukrainy (The Main Features of the Conclusion of Inheritance Contract), Nashe pravo (Our Law), no. 6, 2015, pp. 157-161.

Kysil, V., Diia i tlumachennia koliziinykh norm (Effect and Interpretation of Conflict of Laws Rules) in Dovhert, A. S.; Kysil, V. I. (eds.), Mizhnarodne Pryvatne Pravo: pidruchnyk (International Private Law: Handbook), Alerta, Kyiv, 2014, pp. 172-182.

Lagarde, P., Article 21 in Bergquist, U.; Damascelli, D.; Frimston, R.; Lagarde, P.; Odersky, F.; Reinhartz, B., EU Regulation on Succession and Wills Commentary, Verlag Dr. Otto Schmidt KG, Köln, 2015, pp. 120-125.

Lagarde, P., Article 23 in Bergquist, U.; Damascelli, D.; Frimston, R.; Lagarde, P.; Odersky, F.; Reinhartz, B., EU Regulation on Succession and Wills Commentary, Verlag Dr. Otto Schmidt KG, Köln, 2015, pp. 130-143.

Lagarde, P., Article 24 in Bergquist, U.; Damascelli, D.; Frimston, R.; Lagarde, P.; Odersky, F.; Reinhartz, B., EU Regulation on Succession and Wills Commentary, Verlag Dr. Otto Schmidt KG, Köln, 2015, pp. 144-147.

Lagarde, P., Article 25 in Bergquist, U.; Damascelli, D.; Frimston, R.; Lagarde, P.; Odersky, F.; Reinhartz, B., EU Regulation on Succession and Wills Commentary, Verlag Dr. Otto Schmidt KG, Köln, 2015, pp. 147-150. 
Lagarde, P., Article 26 in Bergquist, U.; Damascelli, D.; Frimston, R.; Lagarde, P.; Odersky, F.; Reinhartz, B., EU Regulation on Succession and Wills Commentary, Verlag Dr. Otto Schmidt KG, Köln, 2015, pp. 150-154.

Li, H., Some Recent Developments in the Conflict of Laws Succession, Recueil Des Cours, Collected Courses of the Hague Academy of International Law, vol. 224, Brill, Nijhoff, Leiden, Boston, 1990, pp. 9-122.

Lipstein, K., Characteristic Performance - A New Concept in the Conflict of Laws in Matters of Contract for the EEC, Northwestern Journal of International Law and Business, vol. 3, 1981, pp. 402-414.

Metallinos, A., Article 23. The Scope of the Applicable Law in Pamboukis, H. P. (ed.), EU Succession Regulation No 650/2012: A Commentary, Nomiki Bibliothiki, C. H. BECK, Hart Publishing, Nomos, Athens, München, Oxford, BadenBaden, 2017, pp. 237-282.

Metallinos, A., Article 24. Dispositions of Property upon Death Other than Agreements as to Succession in Pamboukis, H. P. (ed.), EU Succession Regulation No 650/2012: A Commentary, Nomiki Bibliothiki, C. H. BECK, Hart Publishing, Nomos, Athens, München, Oxford, Baden-Baden, 2017, pp. 283-293.

Nikolaidis, G., Article 3-Definitions in Pamboukis, H. P. (ed.), EU Succession Regulation No 650/2012: A Commentary, Nomiki Bibliothiki, C. H. BECK, Hart Publishing, Nomos, Athens, München, Oxford, Baden-Baden, 2017, pp. 93-109.

Pamboukis, H.; Sivitanidis, A. P., Article 21. General Rule in Pamboukis, H. P. (ed.), EU Succession Regulation No 650/2012: A Commentary, Nomiki Bibliothiki, C. H. BECK, Hart Publishing, Nomos, Athens, München, Oxford, BadenBaden, 2017, pp. 204 -208.

Pohoretska, N., Rozshcheplennia statutu u mizhnarodnomu pryvatnomu pravi (Dépeçage in Private International Law), Prykarpatskyi yurydychnyi visnyk (Prykarpatskyi Law Bulletin), no. 3, 2013, pp. 142-153.

Prokhor, L., Spadkovyi dohovir: praktyka zastosuvannia (Inheritance Contract: Practice of Use), Mala entsyklopediia notariusa (Small Encyclopedia of a Notary), vol. 64, no. 4, 2012, pp. 62 -64.

Proposal for a Regulation of the European Parliament and the Council on the law applicable to contractual obligations (Rome I), COM(2005) 650 final, 15 December 2005.

Postanova Plenumu Verkhovnoho Sudu Ukrainy 'Pro sudovu praktyku u spravakh pro spadkuvannia' (Resolution of the Plenary Session of the Supreme Court of Ukraine 'On court practice in succession matters'), Visnyk Verkhovnoho sudu Ukrainy (Bulletin of the Supreme Court of Ukraine) No. 6 item $17 / 2008$. 
Regulation (EU) No 650/2012 of the European Parliament and of the Council of 4 July 2012 on jurisdiction, applicable law, recognition and enforcement of decisions and acceptance and enforcement of authentic instruments in matters of succession and on the creation of a European Certificate of Succession, OJ L 201, 27 July 2012.

Riabokon, Y., Spadkovyi dohovir (Inheritance Contract) in Zaika, Y.; Riabokon, Y., Spadkove pravo: navchalnyi posibnyk (Succession Law: a Handbook), Yurinkom Inter, Kyiv, 2009, pp. 159-199.

Rodrigo, J. R., Article 25 Agreements as to Succession in Calvo Caravaca, A. L.; Davì, A.; Mansel, H. P. (eds.), SR Commentary, Cambridge University Press, Cambridge, 2016, pp. 381-393.

Roodt, C., Party Autonomy in International Law of Succession: a Starting Point for a Global Consensus?, Tydsrif vir die Suid-Afrikaanse Reg, no. 2, 2009, pp. 241-263.

Sawyer, C.; Spero, M., Succession, Wills and Probate, Routledge, London, 2015.

Shama, N., Pravova pryroda spadkovoho dohovoru (Legal Nature of the Inheritance Contract), Universytetski naukovi zapysky (University Scientific Notes), vol. 18, no. 2, 2006, pp. 144-148.

Sloan, B., Borkowski's Law of Succession, Oxford University Press, Oxford, 2017.

Spasybo-Fatieieva, I., Koiliziia zahalnykh ta spetsialnykh norm (na trokh prykladakh sudovoi praktyky) (Collision of General and Special Rules (In Three Examples of Case Law), Pryvatne pravo (Private Law), no. 1, 2013, pp. 166-175.

Stamatiadis, D., Article 22-Choice of Law in Pamboukis, H. P. (ed.), EU Succession Regulation No 650/2012: A Commentary, Nomiki Bibliothiki, C. H. BECK, Hart Publishing, Nomos, Athens, München, Oxford, Baden-Baden, 2017, pp. 230-233.

Tenenbaum, A.; Chainais, C.; Guilaume G.; Chénedé, F.; Perfumi, C.; Popova, I.; Riehm, T., Part I: Terminology. Chapter I: Contract, in Fauvarque-Cosson, B. ; Mazeaud, D. (eds.), European Contract Law. Materials for a Common Frame of Reference: Terminology, Guiding Principles, Model Rules, Association Henri Capitant des Amis de la Culture Juridique Française and Société de Législation Comparée, Sellier. European Law Publishers, Munich, 2008. https://www. legiscompare.fr/web/IMG/pdf/CFR_I-XXXIV_l-614.pdf (2.11.2018).

Tsyvilnyi kodeks Ukrainy (the Civil Code of Ukraine), Vidomosti Verkhovnoi Rady Ukrainy (Bulletin of Verkhovna Rada of Ukraine) No. 40 item 356/2003.

Tsyvilnyi protsesualnyi kodeks Ukrainy, Vidomosti Verkhovnoi Rady Ukrainy (Bulletin of Verkhovna Rada of Ukraine) No. 48 item 436/2017. 
Tyshchuk, T., The Great Migration: No One in Ukraine Knows How Many of Our Compatriots Have Moved Abroad, https://voxukraine.org/en/the-great-migrationno-one-in-ukraine-knows-how-many-of-our-compatriots-have-moved-abroad (4.9.2018).

Schmidt, J., Artikel 23 EuErb VO in Dutta, A.; Weber, J. (eds.), Internationales Erbrecht: EuErbVO, Erbrechtliche Staatsverträge, EGBGB, IntErbRVG, IntErbStR, IntSchenkungsR, C. H. BECK, München, 2016, pp. 173-199.

Weber, J., Einleitung in Dutta, A.; Weber, J. (eds.), Internationales Erbrecht: EuErb$V O$, Erbrechtliche Staatsverträge, EGBGB, IntErbRVG, IntErbStR, IntSchenkungsR, C. H. BECK, München, 2016, pp. 1-33.

Weller, M., Article 3 - Definitions in Calvo Caravaca, A. L.; Davì, A.; Mansel, H. P. (eds.), SR Commentary, Cambridge University Press, Cambridge, 2016, pp. 115-123.

Wilderspin, M., The Rome I Regulation: Communitarisation and Modernisation of the Rome Convention, ERA Forum, vol. 9, issue 2, 2008, pp. 259-274.

Zakon Ukrainy 'Pro mizhnarodne pryvatne pravo' (the Law of Ukraine 'On Private International Law'), Holos Ukrainy (Vox of Ukraine), no 138/2005.

Załucki, M., New Revolutionary European Regulation on Succession Matters. Key Issues and Doubts, Revista de Derecho Civil, vol. III, no. 1, 2016, pp. 165-176.

Zoumpoulis, C., Article 25-Agreements as to Succession in Pamboukis, H. P. (ed.), EU Succession Regulation No 650/2012: A Commentary, Nomiki Bibliothiki, C. H. BECK, Hart Publishing, Nomos, Athens, München, Oxford, Baden-Baden, 2017, pp. 294-323.

Zoumpoulis, C., Article 26. Substantive Validity of Dispositions of Property upon Death in Pamboukis, H. P. (ed.), EU Succession Regulation No 650/2012: A Commentary, Nomiki Bibliothiki, C. H. BECK, Hart Publishing, Nomos, Athens, München, Oxford, Baden-Baden, 2017, pp. 324-333. 


\section{Sažetak}

Izv. prof. dr. sc. Iryna Dikovska*

\section{UREĐENJE NASLJEDNOPRAVNIH UGOVORA S MEĐUNARODNIM OBILJEŽJEM: TREBA LI UKRAJINA SLIJEDITI PRISTUP EUROPSKE UNIJE?}

U članku se analizira moguće uređenje ugovora o nasljeđivanju s međunarodnim obilježjem prema trenutačnom ukrajinskom Zakonu o međunarodnom privatnom pravu u kojemu, međutim, nisu sadržana posebna pravila koja bi se primjenjivala na navedeni slučaj. S obzirom na to da Uredba (EU) br. 650/2012 Europskog parlamenta i Vijeća od 4. srpnja 2012. o nadležnosti, mjerodavnom pravu, priznanju i ovrsi odluka i prihvaćanju i ovrsi javnih isprava u nasljednim stvarima i o uspostavi Europske potvrde o nasljeđivanju (Uredba o nasljeđivanju) sadržava posebna kolizijska pravila primjenjiva na nasljednopravne ugovore, $u$ radu se iznosi i procjena mogućnosti preuzimanja pravila iz Uredbe o nasljedivanju te u njoj zastupljenih pristupa na ugovor o nasljedivanju koji je priznat u ukrajinskom pravu. U vezi s time je posebno analizirana pravna priroda nasljednopravnih ugovora i kolizijskih pravila prema Uredbi o nasljeđivanju. Konačno se zaključuje da bi većinu pravila Uredbe o nasljeđivanju u vezi s nasljednopravnim ugovorima trebalo preuzeti i u ukrajinsko zakonodavstvo.

Ključne riječi: kolizijska pravila za nasljednopravne ugovore, ugovor o nasljeđivanju, ugovor s nasljednopravnim učinkom, Uredba EU-a o nasljeđivanju, ukrajinsko međunarodno privatno pravo

Dr. sc. Iryna Dikovska, izvanredna profesorica Pravnog fakulteta Nacionalnog sveučilišta Taras Shevchenko u Kijevu, 60 Volodymyrska Street, Kijev, Ukrajina; irinadikovska@hotmail.com;

ORCID ID: orcid.org/0000-0002-0728-3934 
